\title{
IdeAs
}

Idées d'Amériques

$17 \mid 2021$

Villes et culture dans les Amériques

\section{A Journey into Five Decades of Struggles for Indigenous Self-Determination in the Americas: An Interview with Armstrong A. Wiggins}

Laetitia Braconnier-Moreno and Laura Cahier

\section{OpenEdition}

\section{Journals}

Electronic version

URL: https://journals.openedition.org/ideas/11159

DOI: 10.4000/ideas.11159

ISSN: 1950-5701

Publisher

Institut des Amériques

\section{Electronic reference}

Laetitia Braconnier-Moreno and Laura Cahier, "A Journey into Five Decades of Struggles for Indigenous Self-Determination in the Americas: An Interview with Armstrong A. Wiggins", IdeAs [Online], 17 | 2021, Online since 01 March 2021, connection on 06 June 2021. URL: http:// journals.openedition.org/ideas/11159; DOI: https://doi.org/10.4000/ideas.11159

This text was automatically generated on 6 June 2021.

\section{(c) $(7)$}

IdeAs - Idées d'Amériques est mis à disposition selon les termes de la licence Creative Commons Attribution - Pas d'Utilisation Commerciale - Pas de Modification 4.0 International. 


\title{
A Journey into Five Decades of Struggles for Indigenous Self- Determination in the Americas: An Interview with Armstrong A. Wiggins
}

\author{
Laetitia Braconnier-Moreno and Laura Cahier
}

\section{Introduction}

1 Together with the Special Issue on "Social Leaders in Colombia" published in the IdeAs Journal No. 17, Laetitia Braconnier Moreno and Laura Cahier met with Armstrong A. Wiggins to discuss his journey as an Indigenous leader and human rights defender.

2 Born in Nicaragua, he is a Mískito Indian from the village of Karatá, La Moskitia. At the age of 18, he became President of his Karatá community and, in 1972, he became a founding member of AIPROMISU, the first regional Indian organization in La Moskitia that works to defend Miskito rights to self-determination, land, territories, environment, natural resources, sustainable development and their cultural survival. In 1977, Armstrong and other Indigenous leaders from around the world traveled to the United Nations' headquarters in Geneva to demand that the international community hold countries accountable for violating their individual and collective rights. After the Sandinista Revolution of 1979 in Nicaragua, Armstrong became the national representative for MISURASATA, a regional Indian organization in the country. Due to his human rights work in La Moskitia, he was arrested both during the Somoza and Sandinista regimes and was taken as a political prisoner. In 1981, the political situation in Nicaragua forced him into exile. In the United States, Armstrong started working for the Indian Law Resource Center (ILRC) and currently serves as the Director of the Washington D.C. Office. For the past two decades, Armstrong has been actively involved 
with numerous human rights cases involving Indigenous peoples of the Americas at the Inter-American Commission on Human Rights and the Inter-American Court of Human Rights.

3 Due to the Covid-19 pandemic, this interview took place virtually on January $29^{\text {th }}, 2021$ For two hours, Laura Cahier (from France) and Laetitia Braconnier Moreno (from Colombia) discussed with Armstrong A. Wiggins (from Washington, D.C.) about his personal history and long-lasting involvement in the struggles for Indigenous Peoples' rights since the mid-1970s. From criminalization and systemic attacks to other forms of discrimination against Indigenous Peoples, he explored the difficulties that Indigenous leaders from the Americas continue to face in the recognition and implementation of their human rights. Among other things, his remarks specified how the struggles led by Indigenous Peoples for their human rights are situated in relation to, or sometimes in contrast to, other social movements. Advocating for universal education on the rights of Indigenous Peoples, Armstrong engaged in a pedagogical discussion on their legal culture, emphasizing their collective rights to self-determination, land, territory, or cultural survival. Laetitia Braconnier Moreno and Laura Cahier would like to express their deepest gratitude to Armstrong for having granted them this interview. They also appreciate the thoughtful comments and kind reviews from Miranda Carman. ${ }^{1}$

Picture 1: Armstrong Wiggins in Washington, D.C. with the U.S. Capitol in the background, 2012

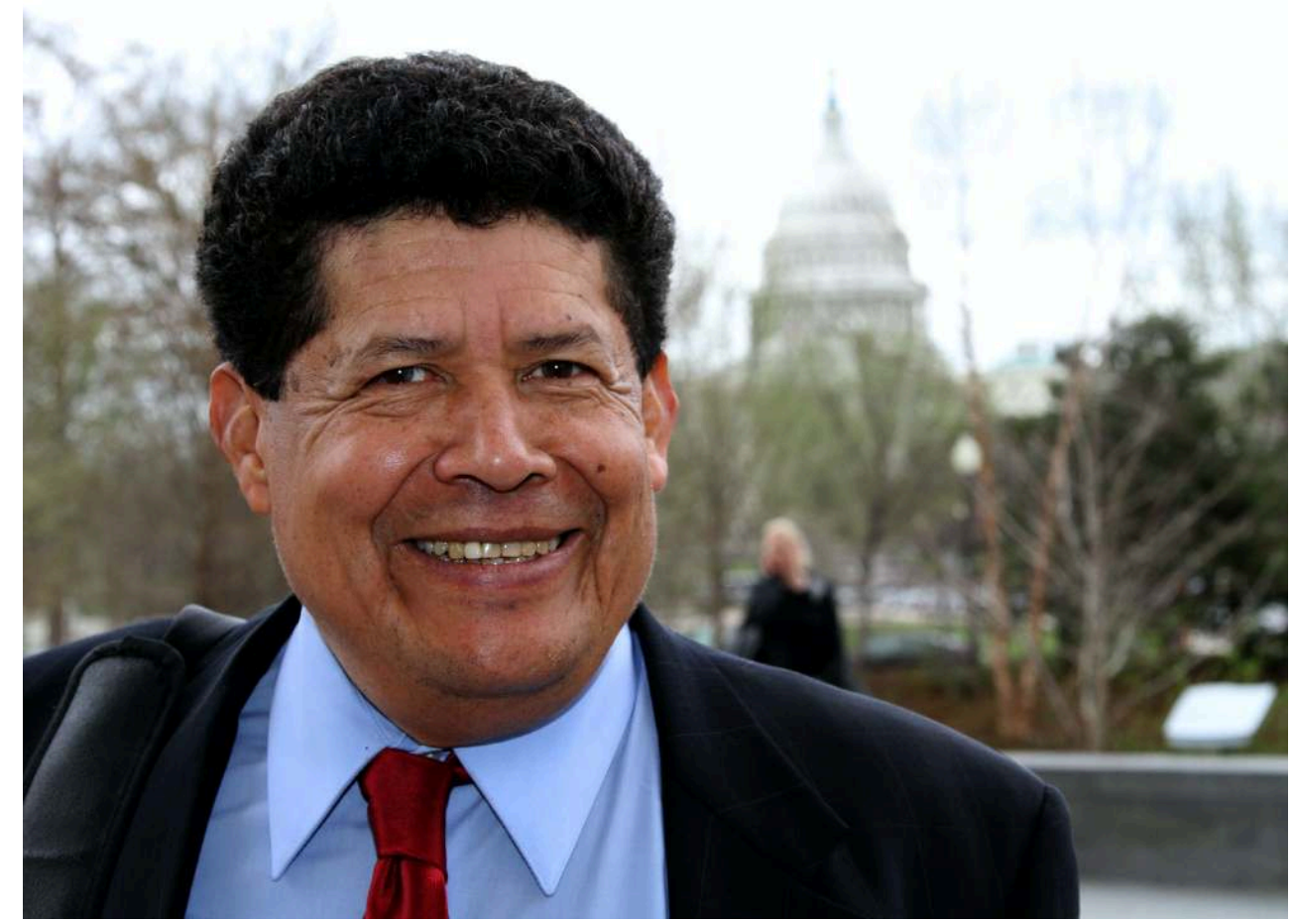

Credits: Armstrong A. Wiggins

Laura Cahier \& Laetitia Braconnier-Moreno (L.C. \& L.B.M.): Thank you, Armstrong, for meeting with us today. We are delighted to discuss the topic of human rights leaders in the 
Americas, based on your own experience and journey. To begin this interview, could you tell us about yourself and your personal journey of becoming a human rights activist?

Armstrong Wiggins (A.W.): My name is Armstrong Wiggins. I am a Mískito Indian from the village of Karatá on the Atlantic coast of Nicaragua, in Central America. I am sure people reading this interview will be wondering: "how come a Mískito Indian person born in the village of Karatá, along the Atlantic coast of Nicaragua, has a name like Armstrong Wiggins?" Well, there is a history and a story behind that name. You see, in our village, there is no doctor, but only midwives to help women deliver their babies. My mother had difficulties giving birth to me and the midwife of the village could not help her. Luckily, there was an American person working in our village who was trained as a medic and who helped save her life. Therefore, my parents decided to give me his last name, Armstrong. I was a baby so I could not say "no" to an American last name! And my last name, Wiggins, is connected to the history of the British protectorate on the Atlantic coast of Nicaragua. You see, the Mískito Indian Nations were never colonized by Spain, nor were they part of the Independent Republic of Nicaragua until England and Nicaragua negotiated the Treaty of Managua and Harrison-Altamirano without the Mískito Nations' consent.

I come from a small village of 27 houses called Karatá; my mother's village was like a paradise before hurricanes Eta and Iota, between a lagoon and the Caribbean Ocean. My father came from the village of Wawa, very close to my mother's village, right by the Caribbean coast. Karatá and Wawa have been on the news lately because two powerful category-4 hurricanes destroyed both villages. ${ }^{2}$ My families are now struggling to survive and to rebuild both villages. It will take a while, but we will rebuild them again. As Indigenous people, we were very poor from a materialistic point of view, but very rich spiritually and with many natural resources. In the past, we could only access a second-grade primary school in my village. The Nicaraguan government was not interested in educating Mískito Indians. I remember that we used to write on slates because we did not have books, nor paper. We had school at my teacher's own house, as there was no school building in the village. Because of the lack of space in her house, some of us were put under the bed, listening to her with the aim of learning.

My father died when I was eight years old; my mother wanted me to stay in my village to help her take care of the animals. Actually, she did not want me to go to school. Her philosophy was that if I went to school, I would then have to worry about all the problems of our community, not just our family's problems. But, if I did not go to school, she thought that nobody would bother me to solve the community's issues and to become a leader, because we were all the same. Now, looking back at it, my mother was right: I should have stayed instead of going to school, but that was not my destiny. After second grade, I could not continue school in my village. At that moment, for some reason, my teacher saw potential in me, especially in science, philosophy and history. My teacher convinced my mother that they found a place for me in a school away from my village, although there was no place for me for a room and board in the city of Puerto Cabezas. I was eight years old at the time. I used to sleep in a general market and to go to school during the day. My mother would drop me off every Monday morning at a port called Lamlaya, then I would walk alone 45 minutes to Puerto Cabezas. She would come back and pick me up every Friday. Then, she and I would paddle in a canoe along the rivers and lagoons to go back to Karatá. 
However, when I was in sixth grade, I got very sick. I eventually ended up in a Moravian Missionary Hospital. But the hospital bill was very expensive for me, because I had no money. I had to negotiate with the director of the hospital to work in order to pay this bill. This is how I met Dr. Ned Wallace, Director of the Hospital, who was trained as an electrical engineer, medical doctor, and former Navy surgeon. He agreed that I could work at the hospital in order to pay my bill. Later, I became one of the four "hospital boys" with room and board at the hospital. Thanks to that, I was able to get my high school education. Because Dr. Wallace was an electrical engineer, surgeon, and a very good politician, he would train me in all those skills while I was going to high school. He took me in like his son and taught me many skills aside from electrical competencies. When I finished eighth grade, I already had an Associate Degree in electronic engineering from the Cleveland Institute of Electronics by correspondence. Dr. Wallace was my teacher, but he also paid for the correspondence school and long-distance education. I then became the person in charge of the electrical, telephone, radio, and electronics systems in that 45-bed hospital. Aside from cleaning hospital floors, painting, cutting grass, and feeding pigs and chickens, I was also interested in engineering and flying airplanes... I would always dream of flying planes and going to the Moon. Anyway, I did go to school abroad to pursue my first career in electrical engineering.

Picture 2: Map of Nicaragua, indicating the villages of Wawa and Karatá

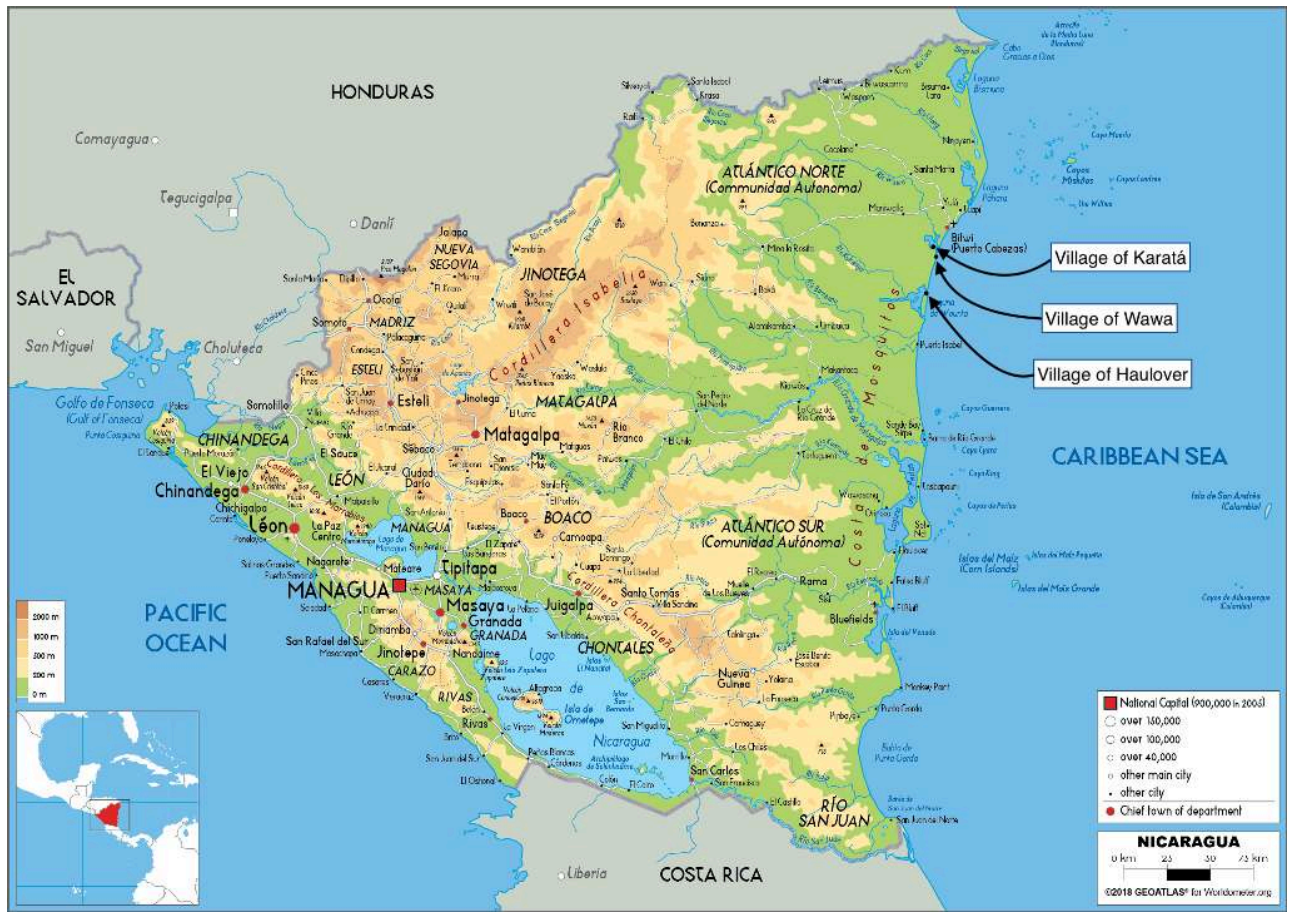

Source: https://www.worldometers.info/maps/nicaragua-map/ (villages of Wawa, Haulover, and Karatá added to the map by the authors).

But, one day, I got a call from my community. They asked me to come back to Nicaragua to work with the University of Wisconsin's medical program. They offered me to be the Director of radio communications and to run their preventive medicine program with medical students and residents from the Big Ten Universities ${ }^{3}$ to study tropical medicine on the Atlantic coast of Nicaragua. Although I also had an offer 
from the U.S. military at that time, the demand from my community was more important to me. I decided to come back to Nicaragua after having been away from home. This is the journey which changed my life from science to Indigenous rights advocacy and Indian politics. Throughout our work on preventive medicine, we would train Indigenous health leaders in the villages on the Atlantic coast of Nicaragua. At some point, we decided to look more in depth at the situation of our own Mískito Nations: how could we educate ourselves so that missionaries, anthropologists, or others would not be speaking for us anymore? We wanted to speak for ourselves, as an Indigenous People. This is how I got deeply involved in Indigenous issues - not only cultural issues, but our political and economic rights issues. Our self-determination rights to govern our people. Our rights to land and territories. Our right to send our young people to school - not just primary and secondary school, but to higher education. Our right to have our own universities on the Atlantic coast of Nicaragua. That became my dream... And I abandoned the dream to go to the Moon.

In 1977, I got a call from a young lawyer named Robert T. Coulter, ${ }^{4}$ from an Indian Institute working with the Six Nations in North America. They asked me to come with them to Geneva to talk about our basic human rights issues for the first time at the United Nations. I was very young at the time, but happy to participate because our government - the government of Nicaragua - did not represent us, nor did it recognize our rights. It was very important for me to understand the old World called Europe, and how European countries, like England, Spain, Portugal or France, came to the Americas during the colonization period, disrespected our civilization, destroyed our existing political and legal systems, and turned us into their slaves... called us less than people, savages. They did not look at us as human beings: they did not recognize our civilization and they wanted to destroy it with big lies. This is why we do not accept being called "ethnic people." We were proud Nations in the Americas before colonization: our governments existed, and we had our own laws. We believe in individual and collective human rights. At the United Nations, we have worked hard to educate Europeans and other Nations, including the Chinese government, about our laws and ways of life. China recognized that we were Nations which had been destroyed by European settlers. However, it did not want their own peoples to be called "Nations," but rather "ethnic groups." The government of India argued the same.

When we first went to Geneva in 1977, we thought that it was time for us to speak up because we were not recognized as Peoples. We had no other place to go but the United Nations with the aim of fighting for our basic human rights and educating Member States about the fact that we have self-determination rights as Peoples. This is why we are not just social movements, because we are still fighting for our basic rights to be recognized like other human beings. Social movements talk about equity, cultural rights, education - that's good, but we, as Indians, have not achieved those rights yet and we are still demanding them. Actually, I think governments love that, because they refuse to hear about human rights, discrimination, and selfdetermination. Governments prefer working with NGOs on social issues, rather than on human rights problems. Human rights are legal rights for us - i.e., legal rights to land, resources, environment, or to govern our own Peoples as Nations. 
Before I went to Geneva in 1977, I thought I was alone in fighting for our rights on the Atlantic coast of Nicaragua... I did not know anybody else fighting for those issues. When I went to Geneva for the first time, school buses came from all over Europe to see "Indians." It was crazy! We could not even get out to our hotels because they were blocking the road. We started talking about the development of international standards for the rights of Indigenous Peoples. At that time, even NGOs were opposed to a Working Group on the Rights of Indigenous Peoples. They wanted us to work with the Working Group on Minority Rights or Slavery, rather than having our own Working Group as Indigenous Peoples. In 1977, we were not recognized as Peoples yet; we were only considered as populations. Still today, France and England do not recognize that we are Peoples that believe in individual and collective rights. This was a very difficult negotiation to overcome, especially with Europeans and others. As a result, it took us from 1977 to 2007 to have political recognition through the United Nations Declaration on the Rights of Indigenous Peoples. ${ }^{5}$ It has been a very uphill battle for us to get recognized as Peoples. One of the main questions that we, Indigenous Peoples from throughout the world, have dealt with is the recognition of our self-determination rights to land and territories. We cannot survive without land and territories as Peoples. Therefore, we decided to fight hard, because the sons and daughters of the colonizers believed that we had no right to land, surface and subsurface. We strongly believe we do, especially in the Americas: our ancestors were in Abya Yala ${ }^{6}$ before the Europeans came. Today, people - especially young people are beginning to realize the importance of those rights. Back in Geneva, in 1977, I realized that I was not alone fighting for our rights. However, when I came back from Switzerland, I was put in jail by the Anastasio Somoza regime. They wanted to intimidate me, because I had spoken against the Nicaraguan government at the United Nations. I can talk about criminalization for years, because it is used against us and to silence our rights. To me, it is easier to win rights, but it is very difficult to implement what we have won. Despite all of that, we still hope to implement the United Nations Declaration on the Rights of Indigenous Peoples (2007) and the American Declaration on the Rights of Indigenous Peoples (2016).

Picture 3: Group photo of the Indigenous delegates from around the world at the close of the Geneva gathering in 1977

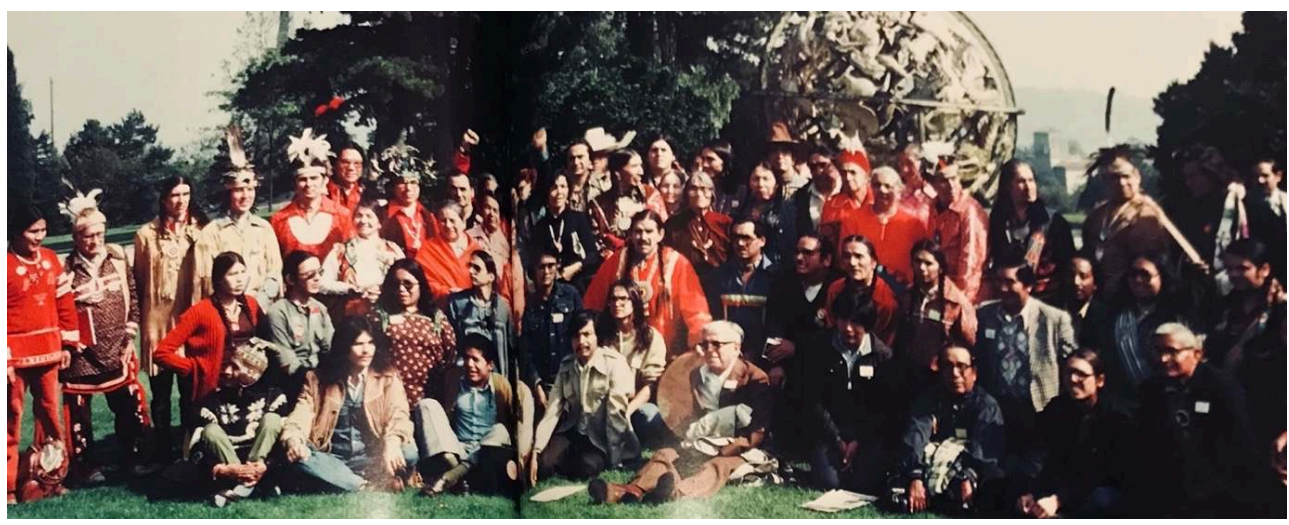

Credits: Armstrong Wiggins

L.C. \& L.B.M.: Thank you for sharing your journey with us. It is enlightening to understand how your personal history is interconnected with self-determination and human rights struggles. In relation with the Special Issue on "líderes sociales" in Colombia, do you think 
the terminology of "social leader" is appropriate? In Colombia, for instance, Indigenous leaders integrate themselves into the category of "social leaders" to build alliances with other defenders, including peasant leaders or women leaders. Do you consider yourself a "social leader"?

A.W.: It is true that we need to unite to fight for our rights. In a paper that I published with the Yale Journal of International Law, ${ }^{7}$ I explain how our struggle is not only with Member States, but also with some human rights organizations which only focus on individual rights, but not collective rights. As Indigenous Peoples, we want both individual and collective rights. This is related to education on human rights. Most education systems come from Europe. This is why the organization that I work for in Washington, D.C. is called the Indian Law Resource Center (ILRC). ${ }^{8}$ We promote Indian law, not European law. Our goal is to educate those who only study colonial legal systems, but do not know about our ways of looking at law and our own legal systems. In Mexico, Central and South America and the Caribbean, Indian law is hardly ever taught in universities, especially law schools. With the ILRC, we organized a training program at the National University of Bogotá, Colombia. Most of our students raised their hands, asking: "why didn't we learn about this before?" Some of them were in tears when they learned that most judges did not know about those legal issues.

What are human rights challenges? Human rights relate to poverty and global inequalities. When it comes to Indigenous Peoples, we are at the bottom - what I mean is that we do not even have equity. We do not own houses costing $\$ 400,000$, we don't own anything actually - not even the lands that we used to live in before colonization. In Colombia, they do not even recognize subsurface rights, they all belong to the States. In many countries, we can only live on the lands, but we do not own them. This is why we talk about human rights, rather than social issues. A second issue is related to discrimination: governments prefer talking about cultural rights than discrimination. Governments prefer talking about social issues than addressing real human rights problems relating to lands and discrimination. They do not want to talk about armed conflicts, violence, killings of Indigenous people, impunity, democracy shortfalls, or weak institutions. Yet, these are basic human rights. This is why we are human rights organizations, rather than social organizations. It does not mean that human rights and social issues do not intersect. We have rights to a good environment, education, and housing systems, of course. However, Indigenous Peoples are not there yet! During the First Summit of the Americas of Indigenous Peoples organized in 2001 in Ottawa, Canada, the topic was economic development. I remember, the First Peoples leaders from Canada wrote a draft statement for the Summit and asked all of us to sign it. However, Indigenous leaders from Mexico, Central and South America and the Caribbean were not comfortable signing this statement because it was not reflecting our reality - we are still fighting for our legal rights! Even if we live in the same continent, Canada and the United States are more advanced in that recognition. The Indigenous Chiefs from Canada did understand the fact that our realities were different. In Mexico, Central and South America and the Caribbean, we are still fighting for our basic human rights - we don't have rights to land yet... We don't have rights to a lot of things, actually! This is why there is a difference between social issues and human rights issues.

It does not mean that we cannot work with other social organizations. However, big environmental organizations do not understand us in that sense. ${ }^{9}$ Some of them still 
don't respect Indian lands: for instance, they develop protected natural areas, without consulting with Indigenous Peoples who have been living there. Today, some social organizations do not want to talk about Indigenous Peoples' right to selfdetermination, own organizations or self-governments. Unlike social organizations, we have a right to self-determination and autonomy. Nevertheless, many big environmental organizations do not want to hear about that, especially because they get money from governmental funds, including the U.S. Agency for International Development (USAID), the World Bank, the Inter-American Development Bank (IDB), or European governments. These governmental funders refuse to hear about selfdetermination and the right to govern our own people. For instance, in Nicaragua, environmental organizations get millions of dollars from USAID to work on environmental issues, but they never work with Indigenous Peoples who actually live on the lands. We are still fighting against that. For instance, the ILRC is working to change the World Bank and the IDB's policies toward Indigenous Peoples. ${ }^{10}$ We are making progress to improve these standards. You see, these are all the reasons why we are different from social organizations - because they only work with central governments, but not with Indigenous Peoples. We would like to work with environmental organizations so they can help create protected areas for Indigenous peoples in which they can govern. With the ILRC, I actually created a Handbook on Human Rights/Indian Rights in 1984 to talk about Mexico's land rights legislation, because most of the work on Indian land had been written by anthropologists who did not understand the idea of collective ownership of land.

L.C. \& L.B.M.: You seem to mention the existence of different legal cultures, especially between indigenous and western systems. It is thought-provoking! Would you like to share some thoughts on the topic of decolonization of law?

A.W.: It is a very important issue. With the ILRC, we challenge discriminatory laws, by working on the conflicts between Western legal systems and Indigenous law. Therefore, we work on law reforms with the aim of educating law schools, law professors, and judges. Although most law schools in Northern America - like Harvard or Yale - now teach Federal Indian Law, we have not reached that point in Central and South America, yet. We organized various seminars in the region, including in Paraguay and in Colombia with the Organización Nacional Indígena de Colombia (National Indigenous Organization of Colombia, ONIC). We organized a third seminar in partnership with the Caribbean Regional Court and Law Schools from Trinidad and Tobago and Guyana. This seminar was a very rich experience because Indian leaders from the Caribbean came as well as judges. We must organize more seminars about Indigenous laws, but we do not have the resources. The Awas Tingni Community v. Nicaragua case, ${ }^{11}$ which we brought to the Inter-American Court of Human Rights, was the first precedent-setting decision about Indigenous land rights. When the American Convention on Human Rights was written in 1969, Indigenous Peoples' land rights were not considered at all. In the text of this Convention, there is nothing about collective rights; only individual property rights are mentioned. However, we were able to use Article 25 of that Convention to explain how many human rights had been violated in relation to land. ${ }^{12}$

Now, Indian movements are becoming stronger. We are here! It is like women's movements saying, "We are here! You can't violate our rights anymore!" Indians have become lawyers; they are trying to challenge and change the laws. This is what the ILRC is all about: it was created by Indian lawyers who initially went to Western 
schools, but for whom this law did not make sense. Therefore, they created the ILRC to represent our Peoples without charging any money. We do not get funds from governments, but we raise our own money to represent our Peoples. We get orders from our elders and leaders - I mean, we don't tell them what to do, but we work with them to develop legal plans. This is entirely different from the attitude of many lawyers who believe that they know about Indian law and tell our leaders how to do it. We need to work together and to educate each other. We need our legal rights first - this is why we are working for our rights to self-government, land, territories, natural resources, and cultural survival.

L.C. \& L.B.M.: Throughout your work with the Indian Law Resource Center (ILRC) and your own experience, have you noticed any form of criminalization of Indigenous leaders by States? If so, what actions has the ILRC taken to deal with this issue and to protect Indigenous leaders?

A.W.: With the ILRC, we have a project dealing with the situation of Indigenous leaders in Brazil. In the 1980s, when we represented the Yanomami People for the first time in Brazil, ${ }^{13}$ there were no Indian lawyers. We were able to raise money to help Paulo Celso Pankararu to become one of the first Indigenous lawyers in the country. Now the situation is different in Brazil because there are dozens of Indigenous lawyers. As they are experts in their own national law, we rather train them on the international human rights systems - the Inter-American System of Human Rights and the United Nations System of Human Rights. When they don't have justice in their own country, we train them so that they can access justice at the regional and the international levels. At the same time, we work with the InterAmerican System to request precautionary measures to protect Indian leaders who are criminalized, threatened, or killed. There are a lot of killings going on in Brazil, Ecuador, Peru, Colombia, Nicaragua, ${ }^{14}$ among other countries. Look at what's happening in Colombia against Indian and Afro-Caribbean leaders: they are killing them!

We also organize this kind of training to expose them internationally: it is very hard to kill Indigenous leaders when they are known abroad, by the international community. When President Obama was elected for the first time, I brought Indian leaders from Central and South America to the White House to meet with the Legal Department. We talked about the criminalization of Indigenous leaders in all countries of the region, and we discussed how the U.S. could help protect them. It was not only about protecting Indigenous leaders, but also human rights organizations and social organizations which were fighting for different issues and being harassed and threatened. One of the Black lawyers from the Legal Department asked me to explain what I meant by "criminalization against Indigenous activists." I said, "Well, I will tell you very quickly. Do you remember when Martin Luther King was fighting for rights in the United States, and they wanted to kill him? That's what I am talking about." She said, "Don't go further, I understand now, I got it!" That's what it is. We must work all together. I hope that, in law schools, they are beginning to talk about that! We really need to learn from each other and to work together.

L.C. \& L.B.M.: You mentioned the precautionary measures granted by the Inter-American Commission on Human Rights to protect Indigenous leaders. This is an example of the legal tools which exist at the international level to protect human rights defenders. More generally speaking, do you think the international human rights system offers sufficient 
guarantees to protect Indigenous leaders facing criminalization and other threats to their right to life?

A.W.: It is still very challenging. I wish I could say that the international system is very efficient in protecting Indigenous leaders. But it is not, especially because of the attitude of certain States and the strong political divisions existing within international institutions, like the Organization of American States (OAS). Some of these divisions reflect the political and ideological issues which subsist in certain countries that do not care for the basic human rights of their people. The situation is still very complicated in many countries, including Nicaragua, Brazil, Colombia, or Peru. For instance, even though the Inter-American Commission on Human Rights grants precautionary measures to protect Indigenous leaders and human rights defenders, some Member States do not respect them. However, we cannot give up! We have to keep pushing and exposing governments. In that regard, communication is very important to educate the international community about these issues and to put pressure on governments.

L.C. \& L.B.M.: With regard to the importance of public communication and media exposure, the ILRC has worked with Indigenous leaders from the Coordenação das Organizações Indígenas da Amazônia Brasileira (Coordination of Indigenous Organizations of the Brazilian Amazon, COIAB) in Brazil. In 2019, they launched an international campaign to denounce the criminalization and killings of Indigenous leaders in the Amazon region, called "Indigenous Blood: Not a Single Drop More." " came to Washington, D.C. in September 2019, the ILRC organized an advocacy tour to meet with Members of the U.S. Congress, the Inter-American Commission on Human Rights, journalists, and other Indigenous organizations. More generally speaking, how does the ILRC communicate efficiently about the need to protect Indigenous leaders and Indigenous Peoples' human rights?

A.W.: Communication is key; hence it is crucial to understand how we do that from Washington, D.C. The Covid-19 pandemic has created a very challenging situation for Indigenous activists and human rights organizations worldwide. It is hard to conduct work like we used to do before the pandemic. Actually, when the COVID-19 crisis started in March 2020, other members from the ILRC and I almost got stuck in Brazil, because we were doing workshops with Indigenous leaders in Manaus! Overall, the situation has become more difficult for Indigenous communities with COVID-19. ${ }^{16}$ We usually try to bring Indigenous leaders from the Americas to Washington, DC. As you mentioned, in September 2019, we brought Indigenous leaders from Brazil in order to meet with Members of Congress, with the U.S. State Department, NGOs, and environmental organizations to educate them about the current situation and ongoing human rights violations in Brazil. ${ }^{17}$ We do not only do that with Brazil, but also with Guatemala. We have a case that we will be arguing before the InterAmerican Court of Human Rights about the land rights of the Maya People in Guatemala. We will either travel to San José, Costa Rica or have a virtual audience, depending on the COVID-19 pandemic. We hope that the decision will be favorable to the demarcation of Indigenous lands in Guatemala, as there is still a de facto apartheid with a minority governing the majority and terrible racism in the country. ${ }^{18}$ Through this legal case, we are hopeful that Indian land rights will be recognized - just like we did with the Awas Tingni Community v. Nicaragua case. 
L.C. \& L.B.M.: It is enlightening to learn how the work of defending the human rights of Indigenous Peoples is simultaneously conducted at various scales - local, national and international. How do you consider yourself in all of that?

A.W.: I consider myself as a "defensor de los derechos de los Pueblos Indígenas" (i.e., defender of the rights of Indigenous Peoples). My main objective has been to work for the defense of Indigenous rights and to educate governments. I traveled all over the Americas, from Saint-Mary in Alaska to "Tierra del Fuego" ("Land of Fire") in Argentina. In the 1980s, when there was a war between the Mískito Nations and the Sandinista Front, we conducted a lot of diplomacy work. ${ }^{19}$ At the same time, 20,000 Miskitos were fighting in the highlands of Nicaragua. But I have never believed in guns. Since I was a child, I have always believed that solutions would be found through legal ways - not war. At that time, President Belisario Betancur of Colombia helped me a lot by offering the Palacio de Nariño to negotiate with the Sandinistas. Trino Morales, who used to be the President of ONIC in Colombia, also helped us. We have a lot of crossed histories with Colombia! I am grateful for the people of Colombia; hence, it is hard to see how much they suffer today. Hopefully, they will make it through this situation!

L.C. \& L.B.M.: You shared key moments of your journey at the international level. We are wondering if you could also talk about your experience in Nicaragua since you had to face political, legal, and physical threats when you were there, especially in the late 1970s and the early 1980s. To a certain extent, there are some similarities with the conflict going on at the moment in Colombia. How were you able to overcome these challenges?

A.W.: We cannot fight alone when issues are so severe - especially in a military conflict. We learned that in Nicaragua: 17 members of my family were executed by the Sandinista army, I was forced into exile, and our people were sent to concentration camps. At the time, we had to deal with the diplomatic aspect of this conflict, but it was not easy. When I went to Geneva in 1977, I was constantly attacked by representatives of the Soviet Union or Cuba when talking about the ongoing issues in Nicaragua. They would accuse me of being a "CIA agent," although I was not funded by any government. The policy of the ILRC says it very clearly and explicitly: we do not accept public money from governments - whether the U.S., European countries, the UN, or the OAS. We raise our own money from private donors. Back at the time, it was very difficult. Aside from Colombia, Spain and Argentina, I must say that the government of President François Mitterrand really stepped up and supported us in Nicaragua. That really helped us save a lot of lives!

I hate war. I don't like war. I want to say that: war is very destructive, and it does not resolve any problems - it actually makes it worse. At the time, MISURASATA was forced to confront the political issues in Nicaragua because 40,000 individuals from our People were in exile, especially in Honduras. It was not easy for us, because we were fighting the Sandinista government supported by Cuba and the Soviet Union and we were also fighting the former right-wing Somoza military dictatorship, called the Nicaraguan resistance or Contras in Honduras and supported by United States and Honduras military. We had difficulties dealing with that situation. A lot of solidarity groups were either supporting the Sandinista government or the Contras. Our family was divided: at that time, most Indian organizations believed in the Leftist organizations. They did not think the Left would also violate their human rights they thought that only the right-wing could do that! The Sandinista propaganda was very powerful, arguing that they were for the people, that they were revolutionary. I 
must tell you this: when it comes to Indians, it was different. And now, Indian leaders start to believe what we had been trying to tell them in the 1980s - the Left or the Right are the same. We believe that the European influence has been so deep in the Americas that there is no American ideology, nor ways of developing our own democracies. Some exceptions can be found in certain Indigenous democracies, especially in isolated communities like in Brazil. I worked a lot with the Yanomami People in Brazil: they were very isolated in the Amazon rainforest. Every ideology what I call the "-isms", such as capitalism, colonialism, Marxism, Leninism - comes from Europe. There is no "Indian-ism" that was developed in a democratic process. Therefore, it is very hard to fight with either right-wing-ism or left-wing-ism. Today, this is also true for the economic development of Indigenous peoples. Either you deal with capitalism, even if this model does not suit Indian Peoples who have a very sustainable economic development, or you deal with Marxism, even if it also hurts Indigenous Peoples. We are thinking about it: if we get all our rights, what will our economic development look like? Look at what happened with Evo Morales in Bolivia: he said he represented an Indian government, but he chose the Marxist-Leninist economic system. Some Indigenous leaders have talked about the adverse effects of these economic models; they have explained that there is no difference for them between a right-wing economic system and the one developed by Evo Morales. For example, the Chiquitanos in Bolivia have been hurt by these economic policies. I think that because of these ideological issues the negotiations were very difficult in Nicaragua. During the third negotiation we had in Mexico thanks to the support of the President Miguel de la Madrid Hurtado, we spent 24 hours non-stop negotiating with the Sandinistas - which called themselves "revolutionaries" - so that the Mískitos would be recognized as Peoples. This was just about the word "People." This is to show how deep the differences are with European ideologies, including revolutionary ideologies. I think it is different now because Indigenous Peoples have learned, in Colombia or Ecuador, that the Left was not really their "friend" either. They are starting to understand what I was saying in the 1980s: both the Left and the Right try to minimize Indigenous Peoples' rights in order to take away their lands and resources. 


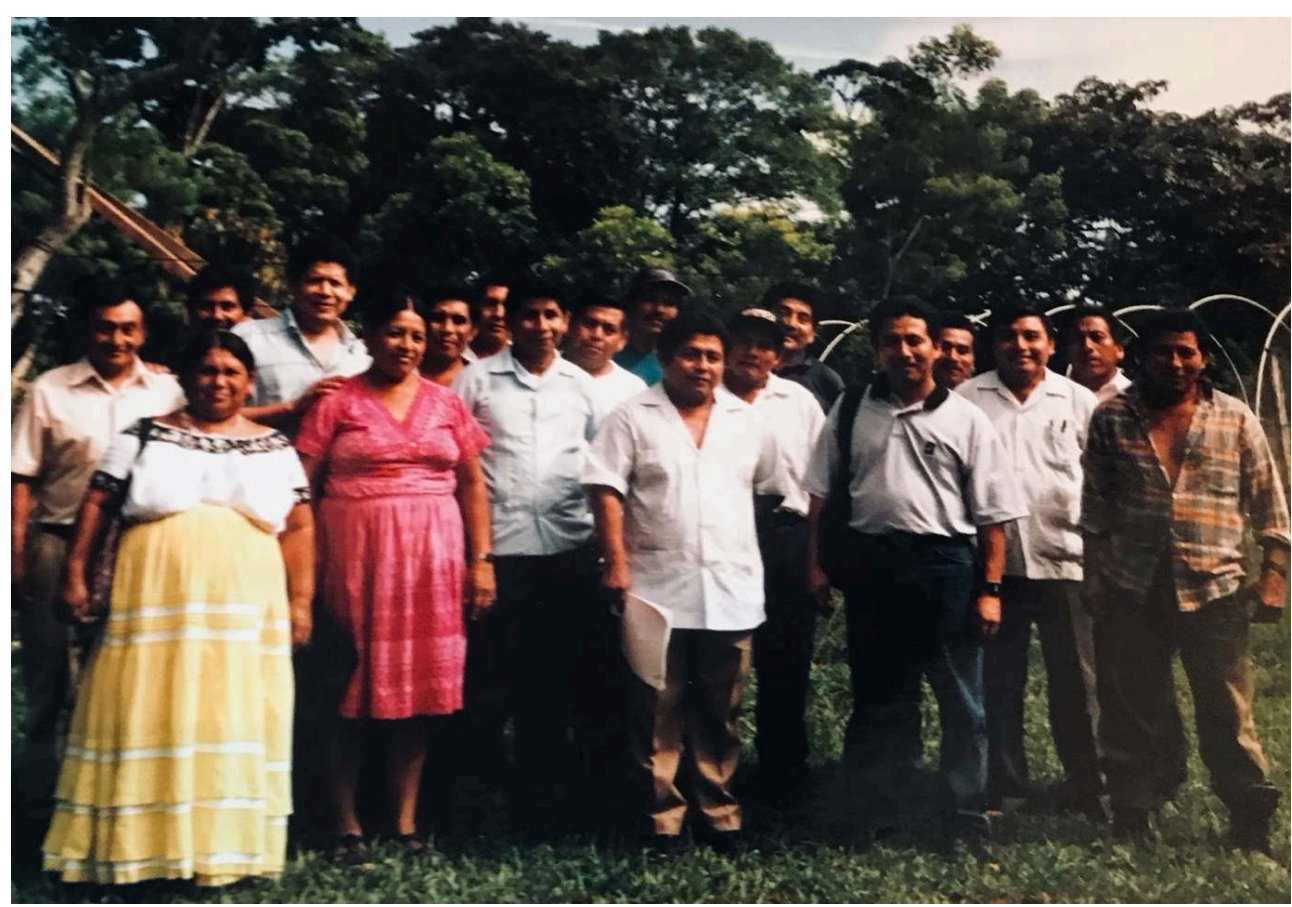

Armstrong Wiggins with Maya communities in Belize in the mid-1990s as they were working on land rights and the creation of a Maya Atlas. See, Maya People of Southern Belize, Maya Atlas: The Struggle to Preserve Maya Land in Southern Belize, North Atlantic Books, 1997. With the ILRC, Armstrong helped advancing the case of the Maya people of southern Belize, who were demanding recognition of their land and resource rights - rights which were completely denied by the Belizean government at the time. The case prompted the creation of a law protecting their rights and was rapidly adopted by Belize's Supreme Court.

Credits: Armstrong A. Wiggins

On the Atlantic coast of Nicaragua, we were able to get the support of the OAS and to negotiate surface and subsurface rights. In the 1980s, the war was very intense between the Mískito Indian Nations and the Sandinista leftist military; the OAS intervened through a peacekeeping mission. ${ }^{20}$ We were also able to set precedents at the Inter-American Court of Human Rights: in the Awas Tingni v. Nicaragua case, the Court ruled that Nicaragua had to recognize surface and subsurface rights and to create a demarcation mechanism to delineate Indian lands. ${ }^{21}$ In Nicaragua, we have central governments, regional autonomous governments, municipality governments, and Indigenous governments. Thus, we divided the land in four parts, with $25 \%$ of the resources from the subsurface going to the central government for education and health issues, $25 \%$ to the regional autonomous governments, $25 \%$ to municipality governments, and $25 \%$ to Indian governments. This had to be decided by the communities in an Assembly. This is where we also have problems. We have what we call the right to free, prior and informed consent (FPIC), because environmental organizations do not want to talk about self-determination rights to avoid challenging governments. Therefore, they created these things like "FPIC" as legal rights for Indigenous peoples. But these are secondary legal rights! Primary rights are self-determination rights. We have experienced cases with one Indian person giving away or selling the collective land titles to a company, while other Indian inhabitants were not even aware of that transaction. It is good to be consulted, but this is not a primary right for us - this is a secondary right. 
I am very concerned about the current situation in Colombia. I don't think it was appropriate to negotiate in Cuba, considering that Cuba was behind the leftist guerilla movement. The problem with Colombia is that Indigenous Peoples were brought in the negotiation process very late. They were not thinking about Indian rights. This is why Indigenous people and Afro-Caribbean descendants are not called Indian Nations, but ethnic organizations. I hope that the agreements will be implemented. I am following the situation very carefully, especially because we work with the Washington Office on Latin America (WOLA) in Washington, DC. We are also talking to ONIC and other Indian organizations to see how we can help based on our own experience in Nicaragua to bring peace. But it is very hard, especially with the present administration in Colombia. I hope Biden's administration will behave differently than Trump's administration did with Colombia. There are so many ideological issues going on over Peoples' rights. I hope the killings stop... But I don't know how this is going to end up. Colombian people don't deserve to be suffering like this.

L.C. \& L.B.M.: Sadly, we see a repetition of comparable facts in different countries of the region. It is interesting to note how Indigenous Peoples have often been associated with the Left or guerrillas in Mexico, Central and South America. Do you think they can also suffer from political stigmatization?

A.W.: You know, I went to jail twice for being an Indigenous activist in Nicaragua: one time during the right-wing administration of President Anastasio Somoza, and a second time during the left-wing administration of the Sandinistas. Today, both sides have some respect for me, because I survived from jail and learned from that experience. I think this is why, in the Americas, we need to develop our own ideologies - not European ideologies. We need to develop our own democratic systems that will work for our people. However, it is hard to change that... Maybe the younger generation will start thinking as the Peoples of Abya Yala, instead of bringing that old ideology from the Old Continent. These European ideologies neither work here, nor in Africa or in the Arab World. I don't know if we can fix that... People have sent their kids to study in England, France, or Spain, and when they come back, they try to make countries in the Americas like Europe, but it does not work. In the meantime, the colonial powers bring all the resources from the Americas to Europe. The U.S. has done the same things: they have brought all the resources to the U.S., but they don't invest in our countries and they don't want us. This is what we see today with the rejection of migrants in Europe or the U.S. The world is in turmoil because of that. Rich countries need to invest in those countries to help them overcome corruption, so that the leaders can take care of their own people. However, this is not happening! If we don't change that, it will be a huge problem, especially with the migration crisis becoming worse. We really need to have a conversation about the ideological impacts on people - we need to talk about how to change that ideology very openly and frankly. Then, we also have the environmental crisis. Look at what's happening to my father's and mother's villages! Both villages were completely destroyed by the two hurricanes a few weeks ago. Earthquakes and oil issues are concerning. Look at Oklahoma, they have earthquakes every day because of oil extraction. Yet, nobody studies how drilling affects the Earth and the future generations. Indigenous Peoples have been talking about these issues, but nobody listens to us because we are not "smart enough" to understand. But we do understand that. So, I think conversation is important. I hope anthropologists also change their 
ways of thinking about Indigenous issues. I remember when I was in my village, two anthropologists came from Germany to do studies about the Mískitos. We would need to give them the permission to study in our communities. We said we could do that, but we also asked them if we could study them... Otherwise, no: we would not accept them in our community! Reciprocity is very important.

L.C. \& L.B.M.: Throughout the interview, you have mentioned the role played by different actors, including States or Development Banks, in relation with Indigenous rights. Today, who do you think are the perpetrators of violence against Indigenous leaders and human rights defenders?

A.W.: Before answering this question, I must say something that I forgot to mention earlier: Indigenous people are also human beings. There are certain vicious circles: when you are poor, it can be hard to get out of those vicious circles. We have been used by other forces, like multinational companies, to harm our own people. There are some individuals who work with the organizations that have been hurting Indigenous leaders and communities. These organizations can be drug traffickers who use Indian lands and territories, violating human rights in Mexico, Central and South America. They can also be mining companies. The natural resources are depleted in Abya Yala and those left are mostly found in Indian lands and territories. When working with the Yanomami community in Brazil, I have seen how the mining companies behave. Mining companies used to shoot Yanomami Indians, just like if they were monkeys. They would kill them or rape Yanomami women because they were not wearing clothes. Mining companies also create a lot of problems within Indian territories - prostitution activities and sex trafficking of Indian women, like in Guatemala. ${ }^{22}$ Logging companies also execute and kill Indian leaders, like in Brazil or in Ecuador. Another problem in Central America is cattle raising business. This violence also happens when one ideological group fights to take power over the country and asks Indian people to choose a side - and if you don't, they just kill you. This is how violence is going on in the Americas. I know several Indian lawyers from Colombia who are in exile today because their life was threatened. Criminalization is happening everywhere in the Americas! They are doing to them what they are also doing with the environment: destruction.

L.C. \& L.B.M.: To conclude on a more positive note, you have mentioned the work conducted by the ILRC to develop legal instruments at the UN and the OAS with the aim of improving the protection of Indigenous leaders. In your opinion, what are the important steps to move forward and strengthen the protection of Indigenous leaders and communities?

A.W.: Today, technology has developed so much that "bad" organizations or Member States cannot get away from human rights violations like they did in the 1980s. More of us are becoming educated and we are aware of how to look for help. Younger generations are becoming more open-minded about these issues as well - whether they are from France, England, the U.S., or all over the world. They better recognize Indigenous Peoples' rights, minorities' rights and women's rights. We are coming together, even in the U.S. - women's movements, Black Lives Matter, Indigenous movements are all coming together! We can now talk to the President, to Senators, to Congressmen and Congresswomen - and they answer to our requests. Those are hopeful signs. With the ILRC, we keep organizing training and workshops with Indigenous leaders, and we are also sharing information. And look at you: you are interested in these issues! I am sure you will keep working on them and writing about 
them. We can now come to Europe to talk about climate issues and go to New York to participate in the United Nations Permanent Forum on Indigenous Issues. The InterAmerican Commission on Human Rights and the Inter-American Court of Human Rights also deal with our issues. Today, when there is no justice within the country, we bring it from outside by using international mechanisms. Even if we still have a long way to go, we are heading in the right direction. The World Bank is also learning about us, doing studies on our lands: they are realizing that Indigenous Peoples manage protected areas better than people from outside who leave once there is no money left to fund them. This is changing, it is an evolving process. I gave up my dream of going to the Moon for another dream: becoming an Indigenous activist and joining the struggle for the realization of Indigenous Peoples' rights. I will not be alive to see this dream come true, but I am hopeful that the younger generation will carry on the work and make it happen.

L.C. \& L.B.M.: Thank you, Armstrong, for your wise words and for sharing your journey with us.

Picture 5: Zoom call with Armstrong Wiggins, Laetitia Braconnier-Moreno, Laura Cahier, 29 January 2021

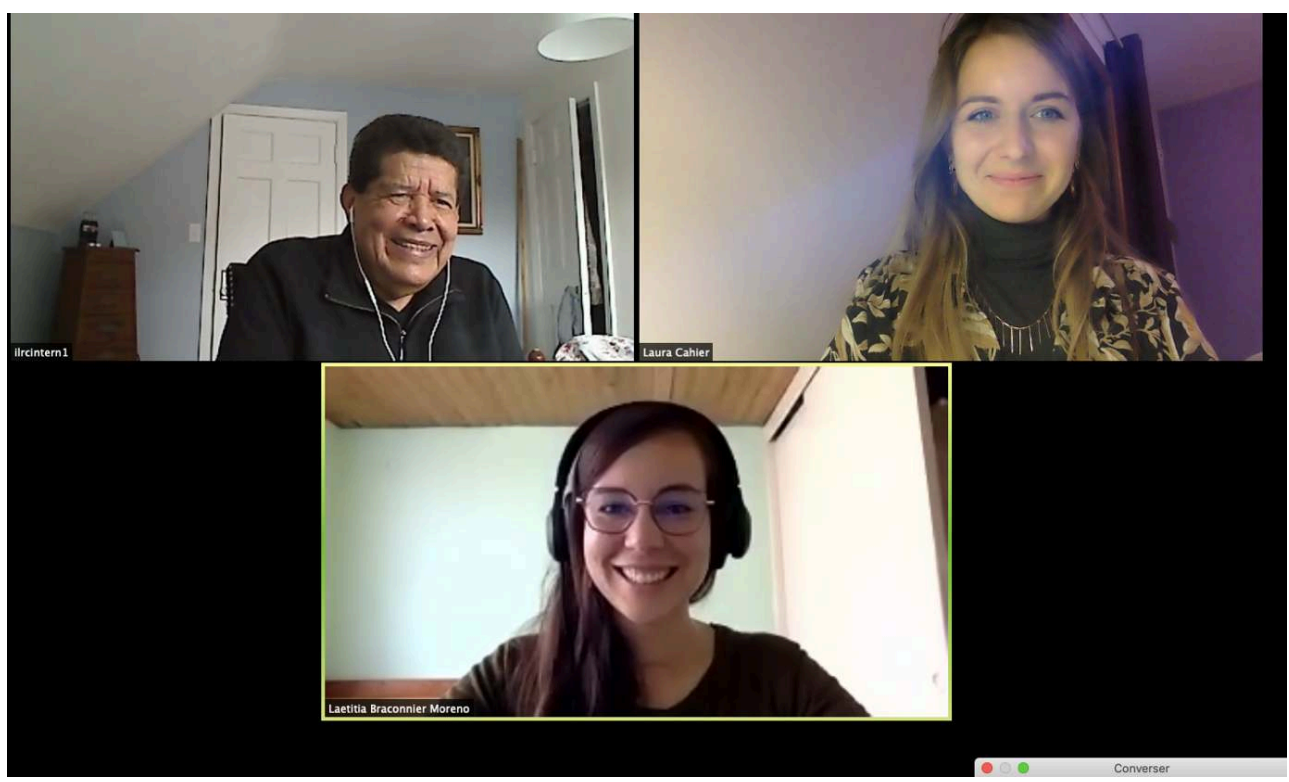

Credits: Laetitia Braconnier-Moreno \& Laura Cahier

\section{NOTES}

1. Miranda Carman is the Program and Administrative Assistant with the Indian Law Resource Center's DC Office. She holds a Bachelor's Degree from the University of New Mexico, and Master's Degree in Latin American Studies from Georgetown University.

2. The Miskito villages of Haulover, Wawa and Karatá were destroyed by two major hurricanes in November 2020. Armstrong mentioned how climate change has disproportionate and devastating 
impacts for Indigenous communities in the Americas, although these environmental issues are often caused by economic activities in which they are not involved. See, video of the New York Times about "Rebuild or Leave 'Paradise': Climate Change Dilemma Facing a Nicaraguan Coastal Town", available at: https://www.nytimes.com/video/players/offsite/index.html? videoId=100000007494833.

3. The Big Ten Universities refer to ten U.S. universities: Ohio State University, Michigan State University, Indiana University, Purdue University, University of Michigan, University of Minnesota, University of Wisconsin, University of Illinois, University of Iowa and University of Nebraska.

4. Robert T. Coulter is Potawatomi Indian and an attorney in Helena, Montana specializing in Native American Law. He serves as the Executive Director of the Indian Law Resource Center.

5. Armstrong A. Wiggins has played a leading role in the ILRC's standard setting work with the United Nations (UN) and the Organizations of American States (OAS), particularly during the adoption of the UN Declaration on the Rights of Indigenous Peoples by the UN on September 13, 2007, and the adoption of the American Declaration on the Rights of Indigenous Peoples by the OAS on June 15, 2016.

6. Abya Yala is the name used by many Indigenous Peoples to refer to the American continent. It is often considered a first step toward epistemic decolonization. The term comes from the Guna language and means "land in its full maturity."

7. Armstrong Wiggins, "Indian Rights and the Environment," Yale Journal of International Law, Vol. 18, 1993, available at: https://digitalcommons.law.yale.edu/yjil/vol18/iss1/14/.

8. To learn more about the history of the Indian Law Resource Center (ILRC), see the timeline of the Center's work since 1978, available at: https://indianlaw.org/content/about-center.

9. See, footnote 7 .

10. Since 2004, Armstrong supervises the Center's international efforts towards standard setting in international bodies such as the UN and OAS and Multi-lateral Development Banks (MDBs), as well as the management of legal cases for the protection of the human rights of the Indigenous Peoples of the Americas.

11. See, the decision of the Inter-American Court of Human Rights, available at: https:// www.corteidh.or.cr/docs/casos/articulos/seriec_79_ing.pdf.

12. Article 25 on the Right to Judicial Protection of the American Convention on Human Rights (1969) states, "1. Everyone has the right to simple and prompt recourse, or any other effective recourse, to a competent court or tribunal for protection against acts that violate his fundamental rights recognized by the constitution or laws of the state concerned or by this Convention, even though such violation may have been committed by persons acting in the course of their official duties. 2. The States Parties undertake: a. to ensure that any person claiming such remedy shall have his rights determined by the competent authority provided for by the legal system of the state; $b$. to develop the possibilities of judicial remedy; and c. to ensure that the competent authorities shall enforce such remedies when granted."

13. In 1979, the ILRC brought the first Indigenous rights case to Inter-American Commission on Human Rights for demarcation of Yanomami land in Brazil. Tragically, the massacre of Indigenous People in Brazil was relatively common during that period. Thanks to the ILRC's involvement, the Yanomami gained protection and were able to self-manage their natural park. See, http://www.cidh.org/annualrep/84.85eng/brazil7615.htm.

14. About the situation in Nicaragua, see the report of the International Federation for Human Rights (FIDH), available at: https://www.fidh.org/es/region/americas/nicaragua/nicaragua-en-2018fueron-asesinatos-desde-2019-matan-nuestros?var_mode=calcul.

15. To learn more about the campaign, see https://en.nenhumagotamais.org.

16. See, e.g., the article published by the ILRC about Indigenous peoples of Brazil denouncing human rights violations during the pandemic before the Inter-American Commission on Human 
Rights, available at: https://indianlaw.org/brazil/indigenous-peoples-brazil-denounce-humanrights-violations-during-pandemic-inter-american.

17. See, e.g., the public hearing organized at the Inter-American Commission on Human Rights on September 27, 2019, https://indianlaw.org/brazil/indigenous-organizations-advocate-enhancedprotections-inter-american-commission-human-rights.

18. See, the open letter written by Armstrong A. Wiggins to U.S. Secretary of States John Kerry about the situation facing the Maya, Xinka, and Garifuna Peoples in Guatemala, available at: https://indianlaw.org/node/988.

19. After the Sandinista Revolution of 1979 , Armstrong became the national representative for MISURASATA, a regional Indian organization in Nicaragua.

20. Armstrong Wiggins assisted Mískito Indian leaders of Nicaragua in seeking support from the Inter-American Commission during the years of civil war between Mískito Indian Nations and the Sandinista leftist government of the 1980s. The ILRC's involvement led to changes in the Nicaraguan Constitution in 1987, concerning the recognition of the lands and territories, cultural identity and forms of organization of Indigenous Peoples.

21. In 1995, the ILRC filed the Awas Tingni v. Nicaragua case which resulted in a landmark ruling by the Inter-American Court of Human Rights in 2001 to protect Indigenous Peoples' right to collective land, environment, and natural resources. The Court found that the Nicaraguan State had violated the Awas Tingni community's rights and established that the State had to adopt in its domestic law "the legislative, administrative, and any other measures required to create an effective mechanism for delimitation, demarcation, and titling of the property of Indigenous communities, in accordance with their customary law, values, customs and mores." As a result of this judgement, Law 445 - also known as the Law of Communal Property Regime of the Indigenous Peoples and Ethnic Communities of the Autonomous Regions of the Atlantic Coast of Nicaragua and of the Rivers Bocay, Coco, Indio and Maiz - was enacted in 2003. This law is unique in the region insofar as it establishes institutions and mechanisms for land demarcation, titling, and procedures for the exploitation of natural resources designed to guarantee the consent of Indigenous communities. See, Asamblea Nacional de la Republica de Nicaragua, Ley No. 445, La Gaceta Diario Oficial, No. 16 del 23 de Enero de 2003, available at https:// www.poderjudicial.gob.ni/pjupload/costacaribe/pdf/Ley_445.pdf.

22. See, e.g., Thematic report of the Inter-American Commission on Human Rights on Extractive Industries and Human Rights (2016), https://www.oas.org/en/iachr/reports/pdfs/ ExtractiveIndustries2016.pdf.

\section{AUTHORS}

\section{LAETITIA BRACONNIER-MORENO}

Laetitia Braconnier-Moreno est représentante du pôle Bogota de l'Institut des

Amériques. Avocate de l'Université Pontificale Bolivarienne (Medellin) et diplômée d'un Master 2 Droits humains de l'Université Paris Nanterre, elle est Doctorante en cotutelle entre cette Université (UMR 70/74, CREDOF) et l'Université Nationale de Colombie (EILUSOS). Elle est coprésidente de la commission « justice transitionnelle » de l'Association des juristes francocolombiens, et ses travaux portent notamment sur les droits des personnes migrantes et des groupes ethniques, et le pluralisme juridique. lbraconnier.moreno@gmail.com 


\section{LAURA CAHIER}

Doctorante en Droit Public à l'Université d'Aix-Marseille (UMR 7318, CERIC - ED67), chercheuse invitée à l'Université de Georgetown et représentante de l'Institut des Amériques à Washington DC. Diplômée d'un Master en Affaires Internationales (Sciences Po Lyon) et d'un Master 2 en Droits de l'homme et Droit humanitaire (Paris 2 Panthéon-Assas), ses recherches doctorales portent sur les droits des femmes autochtones et leur accès à la justice dans les Amériques. Elle est également membre du groupe de recherche « Missing and Murdered Indigenous Women » à Georgetown University. laura.cahier@gmail.com 